\title{
Polite behavior within relational work: The discursive approach to politeness*
}

\author{
MIRIAM A. LOCHER
}

\section{Abstract}

Ever since Brown and Levinson's (1978, 1987) seminal work, politeness research in linguistics has been thriving. It is only in the last couple of years, however, that alternative ways of looking at politeness have been investigated in more detail and have gained more followers. This paper aims at explaining one of these ways - the discursive approach to politeness - and argues for employing the notion of relational work to move away from a dichotomy between politeness and impoliteness. Instead, it is argued that relational work comprises negatively marked behavior (impoliteness/rudeness), positively marked behavior (politeness), as well as nonmarked, politic behavior which is merely appropriate to the interaction in question and not polite as such. The interactants' assessments of linguistic behavior with respect to norms of appropriateness in social interaction is argued to be at the heart of politeness considerations rather than knowledge of prefabricated inherent linguistic devices. These theoretical considerations are illustrated with a discussion of non-elicited, written data.

\section{Introduction}

Brown and Levinson's (1978, 1987) seminal work on linguistic politeness, which is based on the notion of face and on a hierarchy of linguistic strategies that vary in their degree of indirectness, has triggered an enormous number of studies which have employed their research framework, at times uncritically reproducing it, at others vehemently criticizing it (see, e.g., Eelen 2001; Werkhofer 1992). No matter how one considers Brown and Levinson's study today, it is important to acknowledge that virtually every politeness researcher owes much to this classical work, which has influenced our thinking in the last 28 years. Despite arguing that Brown and Levinson did not in fact look at politeness per se, I will 
nevertheless claim that their astute description of linguistic strategies is useful when analyzing linguistic interaction.

Next to Brown and Levinson, there have been other researchers whose work has considerably advanced our understanding of politeness: Lakoff (1973) speaks of 'Rules of Politeness'; Leech (1983) propagates a 'Politeness Principle' with several maxims; Fraser (1990) looks at politeness as the norm and argues that only impoliteness is commented on; Meier (1990) calls for equaling polite behavior with appropriate behavior; Held (1995) and Holmes (1995) stress that there is also a positive, pro-social side to politeness, in opposition to the at times too paranoid interpretations of face-threatening acts adhered to by studies in the framework of Brown and Levinson.

The strand of thinking pursued in this paper, however, started with work by Watts $(1989,1992)$, and has been developed in the last few years (Kasper 1990; Watts 2003; Locher 2004; Locher and Watts 2005). It can be subsumed under the term 'the discursive approach to politeness'. In what follows, I will summarize a number of postulates from this research (2), situate and discuss relational work (3) and the discursive approach to politeness in more detail (4), explain the view that only a small part of relational work is considered to constitute politeness (5), exemplify this view with extracts from naturally occurring data (6), and outline implications for future research on politeness (7).

\section{Postulates from previous discussions (Locher and Watts 2005)}

In our understanding, polite behavior is part of the relational work inherent in all human social interaction. Relational work is described as 'the 'work' individuals invest in negotiating relationships with others' (Locher and Watts 2005: 10) and language is seen as one of its crucial means of communication. In the literature the term facework, which is very similar, has been in use for some time. Relational work is preferred, however, because facework has been employed too often in the literature to refer only to the description of the mitigation of face-threatening acts. It is crucial to recognize that relational work comprises more than just mitigation. In fact, it is understood to cover the entire spectrum of behavior, from rude and impolite, via normal, appropriate and unmarked, to marked and polite.

Furthermore, we argue that, depending upon the kind of verbal social behavior in which individuals engage, they will adapt their relational work to what they have constructed in prior interaction as appropriate behavior. What is perceived to be (im)polite will thus ultimately rely on the interactants' assessments of social norms of appropriateness that 
have been previously acquired in the speech events in question (cf. Mills 2005, for a similar approach).

As a result, we claim - with many others - that no utterance is inherently polite. In addition, we argue that only a small part of what has previously been called polite behavior in the literature will be interpreted as such by interactants. Instead, much of relational work will be perceived as the unmarked norm, rather than as a negatively or positively marked version that we label impolite and polite behavior. I will now proceed to an explanation of the issues raised.

\section{Relational work}

The notion of relational work refers to the interpersonal level of communication as opposed to the ideational level (Halliday 1978). It pays tribute to the fact that people are social beings who use language not only to communicate facts but also to shape their identities vis-à-vis their interactional partners. The theoretical concept underlying this understanding of relational work is the notion of face, as used by Goffman (1967), who derived it from Durkheim (1915). Face is seen as an image which is discursively negotiated (rather than predefined, according to Brown and Levinson). It is 'pieced together from the expressive implications of the full flow of events in an undertaking', i. e., any form of social interaction (Goffman [1955] 1967: 31), and is understood as 'the positive social value a person effectively claims for himself by the line others assume he has taken during a particular contact' (Goffman 1967: 5). It follows that face is socially attributed anew in every social interaction and depends crucially on the uptake of the addressees. It is, in fact, only on loan to us by society, as Goffman puts it:

[W] hile his social face can be his most personal possession and the center of his security and pleasure, it is only on loan to him from society; it will be withdrawn unless he conducts himself in a way that is worthy of it. (Goffman 1967: 10)

The notion of face thus refers to an unstable, external construct that is continually renegotiated in identity construction. In addition, an individual may want to present many different faces, or masks, in the course of interactions, and is not tied to just one single role. I follow Scollon and Scollon (2001: 48) here who claim that there is 'no faceless communication'.

The notion of 'face' has been attacked by researchers who see an Anglo-Western bias in its conceptualization since not every language shares the metaphors of 'losing face', or 'gaining face', or since they disagree 
with the understanding of face as propagated in Brown and Levinson (Gu 1990; Matsumoto 1988; Strecker 1993). It should be stressed that face is a theoretical concept, just like the notion of relational work. Both concepts have a strong explanatory power to investigate social interaction when understood as comprising the entire continuum of interpersonal meaning and the entire spectrum of possible social roles. The discursive approach to politeness, which will now be discussed, is based on this understanding.

\section{The discursive approach to politeness}

In the new introduction to Politeness in Language, Watts (2005: xix-xxii) points out that the distinction between first-order and secondorder politeness introduced in the first edition (1992) is still important today. First-order politeness is seen as the lay person's understanding, while second-order politeness refers to the constructs of theoretical politeness models proposed in the literature (cf. also Eelen 2001). Rather than imposing second-order principles in retrospect on linguistic data, it is important to recognize that terms such as 'impolite', 'polite' or 'appropriate' are inherently evaluative and normative. Watts (2005: xx) argues that such terms

are subject to discursive dispute in that participants in social interaction are likely to differ in attributing these evaluations to individuals' contributions to the interaction.

It is, in other words, not self-evident that a particular linguistic utterance is unanimously perceived as (im)polite by everyone involved in the interaction. Not only would it be a mistake to equate certain linguistic strategies (e. g., mitigation) with politeness from the outset, as mentioned before, but it would be equally inappropriate to expect everybody to agree on the level of relational work employed. We have pointed out elsewhere that just as beauty is in the eye of the beholder, politeness depends on the individual's perception as well (Locher and Watts 2005).

This norm-dependency of politeness is the reason why I previously proposed a definition of politeness which leaves open the possibility of different perceptions (Locher 2004: 91):

Politeness for the speaker:

A polite utterance is a speaker's intended, marked and appropriate behavior which displays face concern; the motivation for it lies in the possibly, but not necessarily, egocentric desire of the speaker to show positive concern for the addressees and/or to respect the addressees' and the speaker's own need for independence. 
Politeness for the addressee:

Addressees will interpret an utterance as polite when it is perceived as appropriate and marked; the reason for this is understood as the speaker's intention to show positive concern for the addressees' face and/or the speaker's intention to protect his or her own face needs. (Locher 2004: 91)

In the definitions just quoted, a speaker may very well aim at using politeness strategies, but there is no guarantee that the recipient will recognize this intention and interpret the level of relational work in the same way. Interactants participating in the same speech event and being familiar with the norms of behavior established in this particular type of interaction over time will of course be more likely to have approximate evaluations than interactants who are newcomers to a particular community. To strike the appropriate level of relational work is thus also a matter of experience and acculturation.

The discursive approach to politeness recognizes the evaluative and norm-oriented character of politeness by claiming that politeness belongs to the interpersonal level of linguistic interaction. It is thus part of relational work, and it is perceived as positively marked when assessed with respect to social norms of appropriateness. What is appropriate cannot be predicted universally and must be addressed at the local level. It is argued that every Community of Practice draws on knowledge about appropriate relational work established in previous interactions. ${ }^{1}$ Such norms are negotiated over time and are subject to change.

This aspect of historicity - stressed by both Ehlich (1992 [2005]) and Sell (1992 [2005]) - explains why many of the instructions for linguistic and non-linguistic behavior that can be found in the literature on proper conduct and etiquette may nowadays be judged as inappropriate, while they were considered appropriate at the time of writing. Consider, for example, the following instructions for young British and German women in the 1960s. The author, Mary Young, published her book in Britain under the title of In Search of Charm in 1962. It was adapted for the German market and published as Schule des Charmes. The extract deals with the appropriate behavior of women in discussions with controversial topics and is given in both languages:

\section{arguing}

Never allow yourself to get 'nettled' or to 'shout down' anyone. Rather take the viewpoint of the man who said: 'I heartily disagree with you, but would defend to the hilt your right to express your opinion.' Or the whole thing is expressed rather nicely in the wellknown French saying 'Chacun à son goût'. And, of course, never 'ar- 
gue the point' with perfect strangers at a place of entertainment over such matters as noise and the wearing of an obscuring hat. If a polite request such as: 'I'm sure you don't realize it, but your conversation (or your hat, as the case may be) is ...' If this approach does not achieve the desired result, then the matter should be referred to an usherette to be dealt with by the management. (Young 1962a: 90)

Teilnahme an einer Diskussion

Geraten Sie bei einer Streitfrage ja nicht in Erregung, und schreien Sie die andern nicht an. Machen Sie sich lieber den Standpunkt des Mannes zu eigen, der gesagt hat: 'Ich bin ganz und gar nicht Ihrer Meinung, lasse Ihnen aber durchaus das Recht, Ihre Ansicht zu äußern.' Die Franzosen drücken diese Einstellung sehr hübsch mit dem Wort Chacun à son goût aus. Natürlich dürfen Sie es nicht zu einem Streitgespräch kommen lassen, wenn Sie im Kino durch einen Hut oder im Konzert durch Geflüster gestört werden. In einem Falle bittet man den Störenfried liebenswürdig, das Übel zu beheben, und wenn dies nicht zum gewünschten Erfolg führt, wendet man sich an Personal oder Direktion, hütet sich jedenfalls davor, in Gekeife auszubrechen. (Young 1962b: 135)

The passages quoted demonstrate historical change with respect to the image that a woman is expected to strive for in public: she is recommended not to stand up for her own ideas and to evade conflict by avoiding confrontation. What is interesting to observe is that the situations mentioned that may give cause for complaint seem trifles to the present-day readership. In addition, there are also differences in the English and German versions. In the British version a woman is asked to utter a 'polite request', while the German version uses the word liebenswürdig ('amiable/kind'). Furthermore, the German version stresses in a free addition to the last sentence of the translation that unladylike Gekeife is to be avoided at all costs. The choice of the word Gekeife is clearly marked as gendered and sexist in German. It does not have an exact translation in English, but can be described as a mixture of nagging and screeching carried out only by women.

In the 1980s, a friend of mine brought the German version of this book, which her mother had been given to study, to the attention of her school colleagues, and we read it with incredulous delight in our free time - not yet appreciating that we owed many of the changes in perception to the women's movement. In retrospect, it seems that we were amused about the differences in norms of proper conduct and indirectly commented on these changes. It is therefore important to point out that changes in what is deemed appropriate in linguistic as well as non-lin- 
guistic behavior can already be observed in one's own life experience, as well as in diachronic approaches to change over longer periods of time. The discursive approach to politeness is aware of these historical changes of norms that are at the basis of judgments on politeness. Let me now turn to a discussion of the importance of these norms with respect to relational work.

\section{Politeness within relational work}

As reported above, relational work is a term that covers the entire spectrum of behavior. Relational work can be 'rude', 'impolite', 'normal', 'polite', 'refined', 'snobbish', 'affectionate', etc. It is especially important to stress that relational work cannot be simply reduced to a dichotomy of impolite and polite behavior. There are many different shades of relational work, and indeed it is even suggested that there is relational work that is neither polite nor impolite.

This point of view is in stark contrast to much of the literature on politeness that implicitly or explicitly only speaks of polite or impolite behavior, but does not leave open the option for a type of relational work that is unmarked, i.e. neither polite nor impolite. Brown and Levinson (1987), for example, discuss politeness as a complex system for mitigating face-threatening acts. They argue that interactants have linguistic strategies at their disposal that allow them to appear polite in various degrees. Behavior that is not considered polite is then implicitly interpreted as impolite. The same dichotomy can be witnessed in Fraser's approach to politeness (1975, 1990; Fraser and Nolen 1981). He argues that politeness is the norm and is not commented on, while impoliteness, which constitutes a breach of this norm, is remarked on by interactants (1990). The same dichotomy between politeness and impoliteness can also be witnessed in Escandell-Vidal (1996) and Meier (1995). In addition, with a few notable exceptions (Beebe 1995; Culpeper 1996, 2005; Culpeper et al. 2003; Kienpointner 1997; Mills 2003, 2005), the 'impolite' side of relational work is neglected in research. ${ }^{2}$

It is argued that there is a type of relational work that is neither polite nor impolite, which can be described as appropriate and politic. The latter term was introduced by Watts in 1989 and is defined as

that behaviour, linguistic and non-linguistic, which the participants construct as being appropriate to the ongoing social interaction. (Watts 2003: 276)

Politic/appropriate behavior can therefore never be impolite. Conversely, it may well be that there are cases of relational work that are perceived 
as politic/appropriate as well as polite. The reason for this is that polite behavior cannot be but appropriate since inappropriateness would turn this relational work into a case of intentional or unintentional overpoliteness, which is often negatively marked. Politic behavior thus entails politeness but cannot be equaled to it on a one-to-one basis. Figure 1 shows the continuum of perceptions of relational work with respect to judgments on (im)politeness, appropriateness, and markedness. (It should be stressed that the speaker's and the addressee's perceptions of the level of relational work may not match. It is exactly these instances that are expected to contribute to the emergence of norms of behavior for a particular discursive practice.)

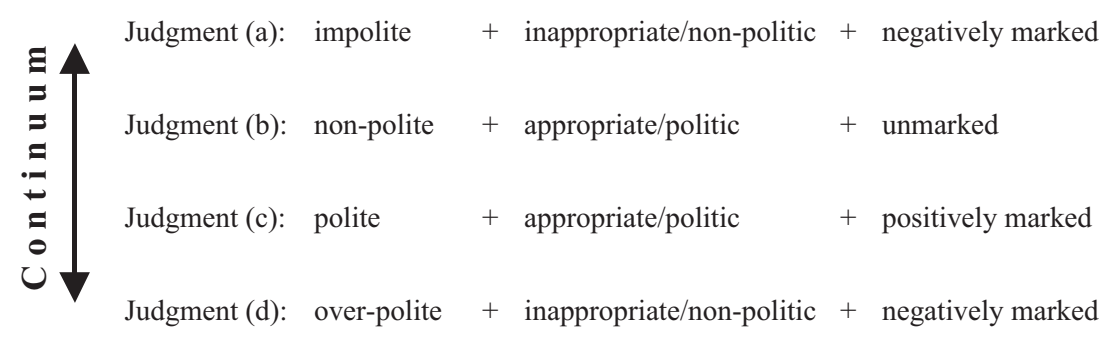

Figure 1. Aspects of the spectrum of relational work.

The concept of politic behavior is clearly a second-order term since it is not in everyday usage. It can, however, be equaled with appropriateness in lay people's perceptions as indicated in Figure 1. It indexes a wide variety of forms of social behavior that include both non-polite and polite behavior.

A visual representation of this understanding of relational work is proposed in Watts (2005: xliii), who wishes it to be understood with the necessary caution valid for all models and visualizations of aspects of social life: the upper half of Figure 2 constitutes appropriate/politic behavior (unmarked and positively marked), while the lower half represents inappropriate/non-politic behavior (negatively marked). The dotted lines stand for the negotiable boundaries between assessments of relational work. In other words, they can shift considerably, reflecting the different norms of appropriateness in different social events and speech communities, as well as changes over time. The arrows in Figure 2 imply that over-polite behavior as well as impolite or rude behavior may be perceived as negative, without claiming that these perceptions are necessarily exactly the same. This area of linguistic behavior is clearly in need of further research.

While it is important to point out that the size of the sections separated by the dotted lines are not based on any empirical evidence of the 


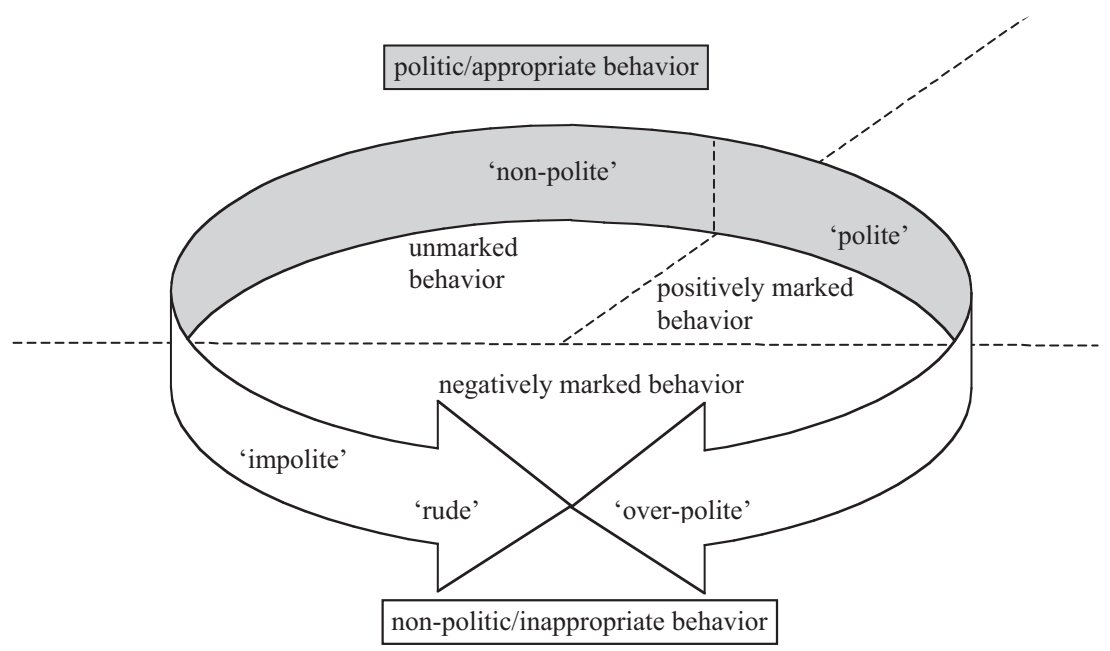

Figure 2. Relational work (Watts 2005: xliii).

different types of behavior, it is suggested that the share of polite behavior (positively marked and appropriate/politic) is much smaller than previously conceptualized in the literature. One of the reasons mentioned above is that the majority of studies do not account for the possibility of non-polite and unmarked behavior in the first place. This means that the proposed distinction necessarily reduces the absolute range of the category 'polite behavior'. The second reason is our conviction that positively marked behavior constitutes a surplus in relational work which would lose its special status and impact if it were to be the unmarked norm. These different types of relational work are also shown in Figure 3 , which presents yet another attempt at visualizing relational work, while being fully aware of the limitations of visualizations of complex social realities as such.

Figure 3 displays how an interactant in a particular speech event may judge relational work with respect to its being politic/appropriate or non-politic/inappropriate. Rude/impolite and over-polite behavior appears as non-politic and inappropriate behavior that is negatively marked. Both polite as well as non-polite behavior appears as politic/ appropriate behavior. Polite behavior, however, is seen as positively marked, while non-polite behavior is the unmarked norm. It is important to point out that any judgment on politeness will thus automatically involve knowledge about expectations of appropriate behavior more generally. In other words, politeness cannot be assessed in isolation, but 


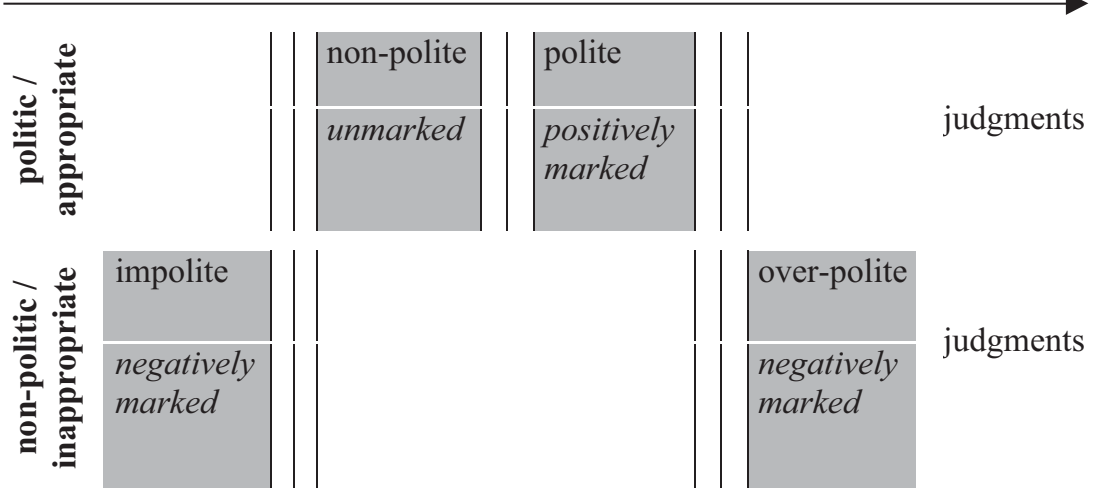

Figure 3. Aspects of judgments on relational work.

needs to be understood with respect to the entire continuum of possible relational work manifestations (cf. Sell 1992: 114). The hatched areas in between the judgments in Figure 3 indicate that the boundaries within relational work are constantly being negotiated, that they are permeable and may shift over time. In addition, they are meant to signal that the boundaries also differ from community to community.

The incentive to be polite in addition to merely appropriate is recognized in the power struggle that interactants engage in. As pointed out before, relational work is the work people invest in negotiating their identities in relationships, and this negotiation consists of confirming or rejecting power differences, closeness and distance, or attributes of a particular face that the interactants present. A good command of appropriate relational work that is in addition marked as 'refined', 'accomplished' or 'polite' may thus be beneficial to the speaker because he or she can demonstrate that the interactional partner's involvement or independence needs have been recognized or that the same needs of the speaker can be signaled to the addressee in a polite way. Alternatively, an interactant may be consciously or unconsciously impolite or overpolite, thus breaching norms of appropriateness, which will have an influence on the relationship of the interactants involved.

\section{Relational work in naturally occurring data}

Considering polite behavior as constituting only a small part of relational work is a departure from mainstream politeness research. To illustrate the difference between a classical Brown and Levinsonian inter- 
pretation of data and the discursive approach to politeness, I will discuss naturally occurring data that does not come from face-to-face interaction, but from a written source. It is taken from the American Internet health column 'Lucy Answers' (the name has been changed), in which a team of professional health educators gives advice to anonymous adviceseekers under the pseudonym 'Lucy'. The target readership consists of young adults. This site, which has been on the Internet for more than ten years, functions like a problem page in a printed magazine or newspaper and thus displays a problem letter by an anonymous advice-seeker and the corresponding response letter by the experts. The topics covered comprise issues of emotional health, relationships, sexuality, sexual health, general health, drugs, and fitness and nutrition. A typical specimen of a problem and response letter can be seen in (1) where a person with a cold and a sore nose asks for remedies:

(1) (general health, 'Red nose')

Dear Lucy,

You know when you get a cold and you have to blow your nose a lot and it gets all sore from rubbing it over and over again with a Kleenex? Do you know of any kind of cream or something that you can put on your nose to help soothe the soreness caused by frequent nose blowing? Any suggestions would be greatly appreciated.

Thanks, Red Nose

Dear Red Nose,

Good, timely question, given the greater number of frequent nose wipers in wintry parts of the world.

Gently massaging some petroleum jelly and/or a moisturizing saline gel as often as possible on a sore nose before or while its skin is raw can help soothe the discomfort and facilitate healing.

To limit or prevent an irritated nose from developing, keep the nose wiping down to a minimum whenever possible - when you've gotta blow your nose, just gently honk your honker instead. Using tissues that have lotions incorporated into them can offer some comfort, as would applying them delicately on a sore nose.

Lucy 
In Locher (2006), I studied 280 of these letters in detail by looking at how they are composed, how exactly advice is given in the response letters and how relational work comes into play. Mitigation was expected to play an important role since advice-giving is generally understood to be face-threatening in an Anglo-Western context. This is because '[b]y telling a hearer what to do, advice can threaten the hearer's identity as a competent and autonomous social actor' (Goldsmith 2000: 235).

My results show that of the 976 advisory moves ${ }^{3}$ identified in the response letters 52 percent are rendered in the syntactic form of declaratives, 36 percent in the form of imperatives and 11 percent in the form of interrogatives. Examples for each category are taken from (1) above and from additional response letters:

\section{Declaratives}

(2) Gently massaging some petroleum jelly and/or a moisturizing saline gel as often as possible on a sore nose before or while its skin is raw can help soothe the discomfort and facilitate healing. (general health, 'Red nose')

(3) Using tissues that have lotions incorporated into them can offer some comfort, as would applying them delicately on a sore nose. (general health, 'Red nose')

\section{Imperatives}

(4) To limit or prevent an irritated nose from developing, keep the nose wiping down to a minimum whenever possible - when you've gotta blow your nose, just gently honk your honker instead. (general health, 'Red nose')

(5) Realize and recognize your loss. - Take time for nature's slow, sure, stuttering process of healing. - Give yourself doses of relaxation and routine busyness. [...] (emotional health, 'Father died')

\section{Interrogatives}

(6) In the meantime, why not work on staying straight for awhile and rationally looking at the positive and negative effects of your tripping? (drugs, 'LSD: Nirvana or burnt out?')

(7) Is it possible that the reason why your parents told you that you shouldn't be kissing is because of religious or cultural reasons, or is it based on the belief that kissing will lead to sexual activity? (sexuality, 'Can you get any diseases from kissing?')

Seeing advice in interrogatives may need further explanation. The sentences in (6) and (7) are interpreted as advice because, if the advisees consider them, they are on their way to solving their problem. The ques- 
tions therefore suggest a specific course of action as in (6) or point to an issue for consideration that may be part of the solution to a problem as in (7).

If we look at the syntactic realizations of the advisory moves once again, we can say that imperatives constitute the more straightforward or less mitigated way of giving advice. In comparison, advice in declarative or interrogative form is more hedged. This is because the face-threatening act of 'telling somebody what to do' is downtoned by means of involving the advice-seeker with a question or stressing optionality in the case of declaratives since the advice is formulated as a suggestion or recommendation rather than as an order. In addition, the examples of declaratives given in (2) and (3) are of a non-agentive type in that the acting subject is not explicitly addressed but only understood to be the advice-seeker. This type of non-agentive declarative advice is preferred (62 percent) and can be claimed to be even more mitigated than the agentive variants. In cases where the advice-seeker is addressed directly, this usually happens with combinations of the pronoun you and the modals can, could, may, and might. Overall, we can thus state that declaratives and interrogatives constitute the more mitigated syntactic renditions of advice that together make up 63 percent of all advisory moves.

The preference for more mitigated syntactic realizations of advice is further supported by the use of lexical hedges such as maybe or perhaps, which are employed to downtone the act of advising. In addition, the overall composition of the response letters further shows a preference for embedding advice in sequences of assessments and general information giving, rather than for plunging directly into the act of advising (cf. [1]). Despite this, we cannot dismiss the fact that 36 percent of the actual advisory moves are realized by means of the more direct imperatives.

Other displays of relational work such as the use of humor to bond with the reader or to hedge an imposition ('just gently honk your honker instead'), the display of empathy, praise ('Good, timely question, given the greater number of frequent nose wipers in wintry parts of the world') or criticism add to the overall tone of the response letters and thus to the particular composition of relational work strategies employed in 'Lucy Answers'.

Where can we locate politeness in 'Lucy Answers'? If a Brown and Levinson approach is taken, we can start our discussion with their formula to establish the weightiness of a face-threatening act: $\mathrm{W}_{\mathrm{x}}=\mathrm{D}(\mathrm{S}, \mathrm{H})$ $+\mathrm{P}(\mathrm{H}, \mathrm{S})+\mathrm{R}_{\mathrm{x}}$ (1987: 76). The weightiness of a face-threatening act $x$ $\left(\mathrm{W}_{\mathrm{x}}\right)$ is the sum of three factors: the value of the distance (D) between the speaker and the hearer, the measure of the power that the hearer has over the speaker $(\mathrm{P})$, and the relative ranking of the imposition $\left(\mathrm{R}_{\mathrm{x}}\right)$ in the particular context in question. The weightiness of the face-threaten- 
ing act then determines which relational work strategy the interactant is going to employ. In 'Lucy Answers' the social distance (D) and power (P) differences between the communicators, i. e., the anonymous adviceseeker and the expert advisors, remain the same in all cases. ${ }^{4}$ The relative ranking of the imposition $\left(\mathrm{R}_{\mathrm{x}}\right)$ can be generalized to constitute advicegiving as such, with differences in the topic categories of advice only. ${ }^{5}$ We would therefore expect the team of professional advisors to pick if not exactly the same - at least comparable relational work strategies in all cases. We would then claim that the choice of a linguistic strategy with redressive action (positive and negative politeness) reflects a higher ranking of the imposition, or, if the relative ranking remains the same, a higher degree of politeness. In a Brown and Levinson approach, the mitigated variants would thus be interpreted as more polite than the realizations of advice with imperatives.

In addition to the problem that the variables in Brown and Levinson's formula are difficult if not impossible to calculate (cf., e. g., Werkhofer 1992), another important point of criticism needs to be made. While it is possible to explain in general the preference for mitigation in 'Lucy Answers' with the face-threatening character of advice-giving, I argue that it is not enough to identify mitigation strategies to claim that we have also witnessed politeness as such. Nor does it seem justified to argue that the imperatives used for giving advice are 'impolite' or automatically 'less polite' than the mitigated variants in this context. Not only are they embedded in the overall composition of the response letter and thus mitigated in their force in many cases, but they also clearly contribute to the straightforward voice that is particular to this Internet health column (cf. Locher and Hoffmann 2006). It would be a mistake to label this directness as being negatively judged (in the sense of 'impolite') from the outset, nor is it likely to be perceived as polite by the readership. Instead, I argue that what we do witness when identifying direct and indirect expressions of advice-giving are different displays of relational work that together form the particular norm of the appropriate and non-polite way of advice-giving established over time in this particular communicative framework by interactants.

The discursive approach to politeness stresses that we first of all have to establish the kind of relational work the interactants in question employ to arrive at an understanding of the then-current norms of interaction. If we find that a mixture of mitigation and directness in advicegiving is indeed the norm - as is the case for 'Lucy Answers' - we have less reason to believe that indirectness is going to be interpreted as polite from the outset. ${ }^{6}$ Instead, the mixture of direct and indirect strategies will be recognized and expected as the norm by the readers. Those who read this site regularly have familiarized themselves with the tone of 
advice-giving established there. They will thus judge relational work against their expectations based on their knowledge of this site. Polite behavior within the range of this particular appropriate relational work will be perceived as positively marked, which is not to say that it has to stick out blatantly. The markedness may in fact be of a very subtle kind, but paying somewhat more tribute to face than expected, while still remaining within appropriate behavior. ${ }^{7}$

This norm-dependency of judgments on politeness also explains why readers who are not familiar with the site and its practice may judge the level of relational work differently. A teenager who usually consults Internet peer advice sites, ${ }^{8}$ which are characterized by the use of nonstandard spelling as well as brief and casual answers in many cases, may indeed judge 'Lucy Answers' as using a 'more polite' way of giving advice. Another reader may take offence at the use of informal vocabulary employed in 'Lucy Answers', judging it as inappropriate to a professional health site. ${ }^{9}$ The reason for this is that their previous acculturation to norms of advice-giving established in other contexts will influence their judgments and perceptions of the level of relational work. We are therefore dealing with an intricate web of norms and expectations that an individual carries into interaction. To simply equate indirectness with politeness fails to account for this fact.

\section{Implications for future research on politeness and concluding remarks}

In the past, politeness research has too quickly been content to describe as polite relational work of the kind that is clearly not rude or impolite. In this way a dichotomy between polite and impolite behavior has been created that falls short of the many shades of relational work and the fluent and negotiable boundaries between the categories proposed in this paper. Nevertheless, it is important to stress that my interpretation of politeness as a marked type of relational work does not devalue the research carried out in earlier frameworks. Brown and Levinson's work, for example, has given us valuable tools for describing strategies for redressing face-threatening acts that are part of relational work. We should not, however, confound their ranking of strategies with degrees of politeness.

Since politeness is norm-dependent and evaluative, the ultimate say in what is considered impolite, non-polite or polite remains with those interactants who are part of a group of interactants who form a discursive practice. As researchers, all we should do is point out instances of relational work that may be open for an interpretation as polite. To do this, we first have to discover what is likely to be the norm of appropri- 
ateness in a given context against which such judgments are made. This will automatically entail studying relational work in all its shades.

Politeness itself can never be conclusively defined with respect to specific linguistic devices, nor can it be universally predicted in a theoretical way. It lies in the nature of politeness to be an elusive concept since it is inherently linked to judgments on norms, and those are constantly negotiated, are renegotiated and ultimately change over time in every type of social interaction. This does not mean that we have to abandon studying politeness. I suggest that the study of relational work in its entire breadth, from its rudest to its most refined ways of manifestation in all types of social interaction, is challenging but rewarding in itself. It will lead to a better understanding of its polite variants and the social functions that they serve.

University of Berne

\section{Notes}

* This text is the revised and considerably expanded version of a paper presented together with Richard J. Watts at the International Pragmatics Conference 2005 in Riva del Garda. I would also like to express my thanks to Richard J. Watts, Andrea Golato and Carmen Nikazm for their constructive comments on this paper.

1. Compare my discussion of the notions of 'frame' and 'schema' with respect to knowledge about appropriate relational work established in previous interactions in Locher (2004: 47-48).

2. The edited book Impoliteness in Language (Bousfield and Locher, in prep.) aims at addressing this research desideratum.

3. In Locher (2006) I used the notion of 'discursive move' to analyze the way in which the content of the letters is structured. An 'advisory move' can consist of several sentences of the same syntactic category and represents one move in the composition of the entire response letter. Other discursive moves are, for example, 'assessment', 'general information giving', or 'farewell'.

4. In the case of problem pages, the advice-seekers automatically assign the role of expert to the 'agony aunt' when they solicit advice. In the case of 'Lucy Answers' this power difference is clearly communicated on the site. The advice-seekers know that they address a team of expert advice givers who are employed by a health services program. In addition, the team of advisors has interactional control over the discourse because they decide which letters to publish and because the response text redefines and interprets the questioner's text (Thibault 1988).

5. The advice topic does indeed influence the overall composition of the response letter as can be seen in Locher (2006).

6. In Locher (2006), I report on a number of studies on face-to-face advice-giving events in which mitigated and non-mitigated forms of linguistic advice-giving occur in combination. These forms constitute the particular ways of advice-giving developed and employed in the different discursive practices.

7. Since the boundary between non-polite and polite behavior is by definition in flux and can never be exactly the same for every member of a discursive practice, I 
have deliberately refrained from giving a linguistic example for behavior that might be considered marked in the context of 'Lucy Answers'. See my comments below on the elusive character of politeness. However, in face-to-face interaction, where it is possible for the researcher to also investigate the reactions to relational work, we can at times point to instances of relational work that may be open for an interpretation as polite by the interactants (see Locher 2004).

8. Consider, for example, the Studentcenter, available at http://teenadvice. studentcenter.org/ [2005, December 17]

9. Compare my discussion of the use of slang words and reactions to these in the reader response section of 'Lucy Answers' (Locher and Hoffmann 2006).

\section{References}

Beebe, Leslie M (1995). Polite fictions: Instrumental rudeness as pragmatic competence. Georgetown University Round Table on Languages and Linguistics 1995, $154-168$.

Bousfield, Derek and Miriam A. Locher (eds.) (in prep). Impoliteness in Language. Berlin: Mouton de Gruyter.

Brown, Penelope and Stephen C. Levinson (1978). Universals in language usage: Politeness phenomena. In Goody, Esther N. (ed.), Questions and Politeness. Cambridge: Cambridge University Press, 56-289.

- (1987). Politeness. Some Universals in Language Usage. Cambridge: Cambridge University Press.

Culpeper, Jonathan (1996). Towards an anatomy of impoliteness. Journal of Pragmatics 25(3), 349-367.

- (2005). Impoliteness and The Weakest Link. Journal of Politeness Research 1(1), $35-72$.

Culpeper, Jonathan, Derek Bousfield and Anne Wichmann (2003). Impoliteness revisited: with special reference to dynamic and prosodic aspects. Journal of Pragmatics $35(10-11), 1545-1579$.

Durkheim, Emile (1915). The Elementary Forms of the Religious Life. London: G. Allen and Unwin.

Eelen, Gino (2001). A Critique of Politeness Theories. Manchester: St. Jerome Publishing.

Ehlich, Konrad (1992). On the historicity of politeness. In Watts, Richard J., Sachiko Ide and Konrad Ehlich (eds.), Politeness in Language: Studies in its History, Theory and Practice. Berlin: Mouton de Gruyter, 71-107.

Escandell-Vidal, Victoria (1996). Towards a cognitive approach to politeness. Language Sciences 18(3-4), 629-650.

Fraser, Bruce (1975). The concept of politeness. Paper Presented at the 1985 NWAVE Meeting, Georgetown University.

- (1990). Perspectives on politeness. Journal of Pragmatics 14(2), 219-236.

Fraser, Bruce and William Nolen (1981). The association of deference with linguistic form. International Journal of the Sociology of Language 27, 93-109.

Goffman, Erving (1955). On face work: an analysis of ritual elements in social interaction. Psychiatry 18, 213-231.

Goffman, Erving (ed.) (1967). Interactional Ritual: Essays on Face-to-face Behavior. Garden City, NY: Anchor Books.

Goldsmith, Daena J. and Erina L. MacGeorge (2000). The impact of politeness and relationship on perceived quality of advice about a problem. Human Communication Research 26(2), 234-263. 
$\mathrm{Gu}$, Yuego (1990). Politeness phenomena in modern Chinese. Journal of Pragmatics $14,237-257$.

Halliday, M. A. K (1978). Language as a Social Semiotic: the Social Interpretation of Language and Meaning. London: Edward Arnold.

Held, Gudrun (1995). Verbale Höflichkeit. Studien zur linguistischen Theoriebildung und empirischen Untersuchung zum Sprachverhalten französischer und italienischer Jugendlicher in Bitt- und Dankessituationen. Tübingen: Gunter Narr.

Holmes, Janet (1995). Women, Men and Politeness. New York: Longman.

Kasper, Gabriele (1990). Linguistic politeness: Current research issues. Journal of Pragmatics 14.2, 193-218.

Kienpointer, Manfred (1997). Varieties of rudeness: Types and functions of impolite utterances. Functions of Language 4(2), 251-287.

Lakoff, Robin Tolmach (1973). The logic of politeness, or minding your p's and q's. Chicago Linguistics Society 9, 292-305.

Leech, Geoffrey N. (1983). Principles of Pragmatics. New York: Longman.

Locher, Miriam A. (2004). Power and Politeness in Action: Disagreements in Oral Communication. Berlin: Mouton de Gruyter.

- (2006). Advice Online. Advice-giving in an American Internet Health Column. Amsterdam: John Benjamins.

Locher, Miriam A. and Sebastian Hoffmann (2006). The emergence of the identity of a fictional expert advice-giver in an American Internet advice column. Text and Talk 26(1), 67-104.

Locher, Miriam A. and Richard J. Watts (2005). Politeness theory and relational work. Journal of Politeness Research 1(1), 9-33.

Matsumoto, Yoshiko (1988). Reexamination of the universality of face: Politeness phenomena in Japanese. Journal of Pragmatics 12, 403-426.

Meier, A. J. (1995). Defining politeness: Universality in appropriateness. Language Sciences 17(4), 345-356.

Mills, Sara (2003). Gender and Politeness. Cambridge: Cambridge University Press. (2005). Gender and impoliteness. Journal of Politeness Research 1(2), 263-280.

Scollon, Ron and Suzanne W. Scollon (2001). Intercultural Communication: A Discourse Approach (second ed.). Oxford: Blackwell.

Sell, Roger D. (1992). Literary texts and diachronic aspects of politeness. In Watts, Richard J., Sachiko Ide and Konrad Ehlich (eds.), Politeness in Language: Studies in its History, Theory and Practice. Berlin: Mouton de Gruyter, 109-129.

Strecker, Ivo (1993). Cultural variation in the concept of 'face'. Multilingua 12(2), 119-141.

Thibault, Paul (1988). Knowing what you're told by the agony aunts: language function, gender difference and the structure of knowledge and belief in personal columns. In Birch, David and Michael O’Toole (eds.), Functions of Style. London: Pinter, 205-233.

Watts, Richard J. (1989). Relevance and relational work: Linguistic politeness as politic behavior. Multilingua 8(2-3), 131-166.

- (1992). Linguistic politeness and politic verbal behaviour: Reconsidering claims for universality. In Watts, Richard J., Sachiko Ide and Konrad Ehlich (eds.), Politeness in Language: Studies in its History, Theory and Practice. Berlin: Mouton de Gruyter, 43-69.

- (2003). Politeness. Cambridge: Cambridge University Press.

- (2005). Linguistic politeness research. Quo vadis? In Watts, Richard J., Sachiko Ide and Konrad Ehlich (eds.), Politeness in Language: Studies in its History, Theory and Practice (2nd revised and expanded ed.). Berlin: Mouton de Gruyter, xi-xlvii. 
Watts, Richard J., Sachiko Ide and Konrad Ehlich (eds.) (1992). Politeness in Language: Studies in its History, Theory and Practice. Berlin: Mouton de Gruyter.

Werkhofer, Konrad T. (1992). Traditional and modern views: The social constitution and the power of politeness. In Watts, Richard J., Sachiko Ide and Konrad Ehlich (eds.), Politeness in Language: Studies in its History, Theory and Practice. Berlin: Mouton de Gruyter, 155-197.

Young, Mary Frances Thornton (1962a). In Search of Charm. Leicester: Brockhampton Press.

- (1962b). Schule des Charmes. München: William Goldmann Verlag. 